\title{
De verbeelding van de
}

\section{diagnostiek}

Inaugurale rede

Rede uitgesproken bij de aanvaarding van het ambt van hoogleraar in de

Psychodiagnostiek, in het bijzonder de diagnostische besluitvorming aan de

Faculteit der Sociale Wetenschappen aan de Katholieke Universiteit Nijmegen op

25 juni 2003

door dr. Cilia L.M. Witteman 
Vormgeving en opmaak: Nies en Partners bno, Nijmegen

Drukwerk: Janssen Print Nijmegen

\section{ISBN 90-9017060-x}

\section{(c) Cilia L.M. Witteman, Nijmegen, 2003}

Niets uit deze uitgave mag worden vermenigvuldigd en/of openbaar worden middels druk, fotokopie, microfilm, geluidsband of op andere wijze dan ook, zonder voorafgaande schriftelijke toestemming van de copyrighthouder.
Mijnheer de Rector Magnificus,

gewaardeerde aanwezigen,

geliefde vriendinnen, vrienden en familie,

Beslissen is vreselijk moeilijk. Je kiest een optie waarvan je hoopt en verwacht dat die je belangen dient of je behoeften bevredigt of tenminste je situatie niet verslechtert; maar met het maken van die keuze sluit je andere opties uit. En wie kan je garanderen dat een andere optie bij nader inzien niet veel lucratiever zou zijn geweest? Je probeert om niet op het verkeerde keuzepad te raken, door voordat je beslist eerst zoveel mogelijk informatie te verzamelen over je opties, door goed na te denken over wat je nu eigenlijk wilt en door scenario's te verzinnen: wat gebeurt er als ik dit kies, en wat als ik de andere optie neem? Daar kun je je kennis van zaken bij inzetten en je creativiteit bij gebruiken, maar de toekomst heeft een onhebbelijke eigenschap: ze is onzeker. Zelfs al zou je alles weten over je huidige situatie en je opties, je zult altijd op z'n best achteraf weten of je goed gekozen hebt. Ik stond voor de beslissing bij de Universiteit Utrecht te blijven, waar het werk prettig was, ik erg fijne collega's had, waar ik in een kwartiertje naar toe fietste zodat ik 's middags sne thuis kon zijn om de meiden na hun schooldag op te vangen, maar waar ik niet meteen toekomstmogelijkheden zag; ò zou ik naar het oosten des lands gaan, als hoogleraar, waar ik niet wist of de samenwerking met collega's goed zou zijn en waar ik ver voor moest reizen? $\mathrm{Nu}$, na 9 maanden hier in Nijmegen, denk ik dat ik de goede beslissing genomen heb.

Er zijn allerlei hulpmiddelen om een dergelijke keuze te vergemakkelijken. Je kunt een aftelrijmpje gebruiken, zoals lene Miene Mutte. Of je kunt je opties vergelijkenderwijs beschrijven, in een matrix, op een aantal dimensies, zoals bijvoorbeeld praktische zaken, collega's en carrièreperspectief. Elke optie waardeer je dan op elk van die dimensies, bijvoorbeeld op een schaal van o tot 10. Dan tel je de waarderingen simpelweg op en kiest voor de hoogst scorende optie (zoals in Multi-Attribute Utility Theory of MAUT, zie bv. Baron, 1995). Het klinkt zo plausibel om het zo te doen, je voorkomt dat je dingen over het hoofd ziet, maar wie heeft ooit op zo'n manier een belangrijke beslissing genomen? Misschien doen we dat niet omdat we maar beperkt rationeel zijn, en omdat we ons gevoel als we ons een optie voorstellen niet kunnen kwantificeren. Je merkt of je blij wordt of niet als je jezelf in de ene of de andere 
toekomstige situatie voorstelt. Je probeert je te verbeelden of je spijt zult krijgen van je keuze als die achteraf niet uitpakt zoals je verwacht had (zoals beschreven in Regret Theory, zie bv. Loomes \& Sugden, 1982). Dergelijke emoties geven vaak de doorslag Maar emoties zijn geen statische of objectieve feiten. Je kunt ze (soms) sturen, ze kunnen van dag tot dag veranderen en zelfs per uur verschillen. Soms neig je ertoe risico's te nemen, en soms houd je alles liever bij het bekende oude. Je kent de beperktheid van je voorstellingsvermogen, van je kennis van zaken, van de voorspelbaarheid van de toekomst - en toch moet je beslissen.

De situatie wordt echt hachelijk als je, uit hoofde van je deskundigheid, moet beslissen over anderen. Pech als je voor jezelf het verkeerde kiest; vreselijk als je voor een ander de verkeerde beslissing neemt. Denk aan een psychotherapeute die beslist haar depressieve cliënte niet op te laten nemen omdat zij de kans op suïcide niet hoog inschat en die gebeld wordt dat een zelfmoordpoging geslaagd is; of stel je je een rechter voor die iemand veroordeelt wegens incest, terwijl later blijkt dat het vermeende slachtoffer alles verzonnen heeft. Dit zijn extreme voorbeelden, maar de verantwoordelijkheid beslissingen te nemen waarvan het welzijn en soms het leven van een ander afhangt, is zwaar. Zo'n verantwoordelijkheid hebben psychodiagnosten ook. Ook zij nemen beslissingen waar het welzijn van hun cliënten van afhangt. Er wordt van ze gevraagd te verklaren waarom iemand bepaalde klachten heeft, en daa wordt vervolgens de behandeling op afgestemd. Hoewel zelden leven en dood betreffend, is ook dit soort beslissing geen sinecure, omdat het verstrekkende gevolgen kan hebben voor het leven van de hulpvragende (Ter Laak \& De Goede, 2003). De diagnost moet zich een beeld vormen van wat er aan de hand is, inschatten hoe zwaar de problemen zijn en er achter komen welke omstandigheden of gebeurtenissen bijgedragen hebben aan het ontstaan. Hoe pakken diagnosten dit aan? Ik stel me voor dat hulpverleners (therapeuten, artsen) die een diagnostische beslis sing moeten nemen, naar hun cliënte kijken, luisteren, vragen stellen en zich van die persoon en haar situatie een beeld vormen. Zo'n beeld lijkt, vermoed ik, op een verhaal, dat begint met "Er was eens .." en dat (in dit geval, helaas) eindigt met “.. en ze leeft daarom nu zo ongelukkig". Een voorbeeld: de klacht van Dafne dat zij zich niet kan handhaven op school wordt begrepen in een verhaal van een meisje met een driftige aanleg, vroegkinderlijk onvermogen onenigheden met ouders uit te praten, verlies van moeder op 10-jarige leeftijd en steeds terugkerende pesterijen om haar oranje haar, waarbij nu conflicten met klasgenoten en leerkrachten uit de hand lopen. De klachten worden in dit verhaal begrepen als logisch voortvloeiend uit wat er eens was (de vroege jeugd, biologische factoren), wat er allemaal gebeurde (de omstandigheden, de levensloop), en hoe het zo mis kon gaan (de aanleiding tot de hulpvraag).

Ik zal hier deze verhalende verbeelding van de diagnostiek uitwerken en onderbouwen, en er de consequenties van schetsen voor onderzoek naar, onderwijs in en praktijk van de diagnostische besluitvorming.

\section{Psychodiagnostiek}

Psychodiagnostiek is het analyseren van persoonlijke of gedragsproblemen door het verzamelen van informatie met behulp van tests, observaties en interviews en het zoeken naar verklaringen van en oplossingen voor die problemen met behulp van wetenschappelijk-empirische kennis. Een groot verschil tussen psychologische en medische diagnostiek is dat de gedragswetenschap nog geen compleet stelsel van wetten kent en clinici nog geen volledig kennisbestand (Krol, De Bruyn \& Van den Bercken, 1992), zodat het bij psychische ziektes (nog) niet zonder meer mogelijk is specifieke oorzaken of ziekteverwekkers aan te wijzen (Ter Laak, 1995; Ter Laak \& De Goede, 2003). De medische stand daarentegen beschikt over een veel rijker arsenaal aan causale theorieën, nosologische modellen en prototypische definities van ziektes (Patel \& Ramoni, 1997).

Doel van de psychodiagnostiek is het verhelderen, onderkennen, verklaren en indiceren, met behulp van psychologische instrumenten en theorieën. Verklarende diagnostiek komt neer op het doen van (empirisch) getoetste uitspraken over condities die, afzonderlijk of in samenhang, de probleemsituatie in het individuele geval verklaren. Verklaren betekent aangeven welke factoren het probleem veroorzaken, uitlokken, in stand houden en beïnvloeden. Als basis voor reglementering van het diagnostisch proces geldt in Nederland een model gebaseerd op de structurering van wetenschappelijk onderzoek, in 1961 door De Groot in zijn methodologieboek beschreven als de "empirische cyclus" (De Groot, 1961). Van Strien stelde in 1984 een 'regulatieve', meer op de praktijk toegesneden variant voor (Van Strien, 1984). Tegenwoordig is, in Nederland en België De Bruyn's Diagnostische Cyclus (De Bruyn, 1992; De Bruyn et al, 1995; 2003) het invloedrijkst, met als grondstructuur dezelfde empi- 
rische cyclus, waarin het geheel gezien wordt als een beslisprobleem (Vertommen, Ter Laak \& Bijttebier, 2002). Het diagnostisch proces wordt ook wel beschreven als een proces met achtereenvolgens een diagnostische vraag, ongestructureerde dataverzameling, hypothesevorming, gestructureerde dataverzameling en hypothesetoetsing (Westenberg \& Koele, 1993; vergelijk ook Vertommen, 2002; Kievit, Tak \& Bosch (2002) die interventie en evaluatie toevoegen). Hypothesevorming is een inductief proces waarin een creatief en heuristisch element een rol speelt. Ik heb het over het verhaal dat daar achter zit.

\section{Het denken van de diagnost}

Een verhalende of narratieve diagnostische praktijk is achterhaald en staat terecht slecht aangeschreven door de associatie die het wekt met subjectiviteit en willekeur. Zo'n 20 jaar geleden is deze praktijk door de meerderheid van de diagnosten verworpen ten gunste van een wetenschappelijker, gestructureerder benadering zoals bijvoorbeeld beschreven in de diagnostische cyclus. Wat ik voorsta is ten enenmale niet een terugkeer naar een intuïtieve aanpak, of naar een "verstehende", hermeneutische diagnostiek (Lubbers, 1985). Ik pleit niet voor het overboord gooien van empirische toetsing of wetenschappelijke fundering. Ik pleit wel voor een herwaardering van de cognitieve vermogens van de hulpverlener, en ik pleit er met name voor dat onderkend wordt dat diagnosten hun cliënten niet als een losse verzameling gegevens zien. Gegevens spreken nooit voor zich, ze krijgen pas betekenis vanuit een theorie of binnen een kader (Doerbecker, 1985). Mensen geven direct kop en staart aan informatie, ze representeren die automatisch in een begrijpelijk geheel, zoals bijvoorbeeld een verhaal. Het gaat mij om inzicht in hoe de hulpverlener in staat is zich uit de grote hoeveelheid heterogene informatie over een cliënte een samenhangend beeld te vormen dat het probleem verklaart. Daarbij vormen de kennis en ervaring van de diagnost het kader waarbinnen informatie over de cliënte verworven en verwerkt wordt. In modellen als de diagnostische cyclus is dit impliciete hermeneutische moment niet meer zichtbaar (Van Strien, 1985), maar ik wil beweren dat het er wel degelijk is, en dat het de hypothesevorming stuurt. In plaats van dit moment als subjectief te verwerpen is het constructiever te bestuderen hoe het werkt, om daarmee het inzicht in feitelijke diagnostische processen te vergroten. Uiteraard gebruikt de diagnost zoveel mogelijk 'evidence', empirische kennis. Maar mij dunkt dat het integreren van al die informatie tot een coherent beeld iets extra's vereist, dat niet tot zijn recht komt in hypothesetoetsende modellen. Ik zou dat "iets extra's" willen vatten, om het de plaats te geven in modellen van het diagnostische proces die het feitelijk inneemt. Ik houd geen pleidooi voor fenomenologie in plaats van hypothesetoetsing, maar voor het onderkennen van een fenomenologisch moment bij het genereren van hypothesen of tentatieve verklaringen (Carlier \& Schoorl, 1990). Want alle checklists, gestructureerde interviews en genormeerde psychome trische tests bij elkaar geven nog geen diagnose. Het cognitieve proces waarin de psychodiagnostische beslissing tot stand komt, behelst méér dan het optellen van alle testuitslagen. Het is onbevredigend dit 'meer' alleen aan te duiden met verder niet gespecificeerde begrippen als 'ervaring' of 'intuïtie' (Derksen, 2001), 'de klinische blik', of 'ongewapend oordeel' (De Bruyn et al., 1995; 2003). De vraag is wat dergelijke begrippen inhouden, waaruit de cognitieve expertise van de diagnost bestaat. Analoog aan Het Denken van den Schaker (De Groot, 1946) en Het Denken van de Neuroloog $($ Snoek, 1989) staat Het denken van de Diagnost hier centraal - niet om te betogen wat daar allemaal mis mee is, maar juist om te begrijpen hoe de diagnost in staat is haar expertise uit te oefenen. Hoeveel onderzoek er ook al is gedaan naar psychodiagnostiek, er zijn weinig protocollen verzameld en geanalyseerd over hoe diagnostische processen verlopen (Ter Laak \& De Goede, 2003; maar zie bv. Witteman \& Kunst, 1997; Denig, Witteman \& Schouten, 2002). Methodologisch is het lastig de diagnostische verbeelding in kaart te brengen, maar het kan, en het moet wel gebeuren (Caspar, 1997), omdat zo'n kaart de aanknopingspunten markeert voor optimalisatie van het proces. Want intussen is al wel duidelijk geworden dat het informatieverwerkingsproces ook bij diagnosten suboptimaal verloopt en ondersteuning verdient.

\section{Diagnostische besluitvorming}

Bij de psychologische besliskunde vinden we een overdaad aan onderzoek waarin overtuigend is aangetoond dat het voor mensen maar zeer beperkt mogelijk is zonder vooringenomenheid te beslissen. Mensen kijken ten eerste selectief naar informatie en wegen niet alles mee in hun beslissing en vervolgens gebeurt het afwegen van de geselecteerde informatie ook niet belangeloos of objectief.

Er is, beginnend met Nobelprijswinnaar Kahneman en zijn helaas overleden collega 
Tversky (Tversky \& Kahneman, 1974), een traditie ontstaan van onderzoek naar beoordelen en beslissen, waarin men systematische afwijkingen vindt in vergelijking met economische of logische standaards. Mensen blijken gebruik te maken van heuristieken, mentale 'shortcuts', waardoor hun oordelen 'biases' (vertekeningen) vertonen, bevooroordeeld zijn (zie ook Evans, 1989; Nisbett \& Ross, 1980; Witteman, 1992). Je weegt nooit alle mogelijke informatie mee in een beslissing; dat is praktisch ook ondoenlijk. Je maakt een selectie. Uit onderzoek blijkt dat mensen informatie voor verdere overweging selecteren op basis van de beschikbaarheid en representativiteit van die informatie (de zogenaamde 'beschikbaarheids' respectievelijk 'representativiteits'-heuristiek). Beschikbaarheid wil zeggen: makkelijk uit het geheugen op te roepen, bijvoorbeeld omdat het een opvallende gebeurtenis betreft of juist omdat het zo vaak voorkomt. Dat een cliënte groene haren heeft valt meer op dan dat zij zich niet zo makkelijk uit. Daardoor kan dan extraversie eerder de conclusie lijken dan introversie, temeer daar het over het algemeen extraverte mensen zijn die hun haren een opvallende kleur geven. Als je moet oordelen over iemand die een representante lijkt van een bepaalde categorie mensen, dan zul je andere kenmerken die horen bij die categorie mensen ook aan deze persoon toeschrijven. Als Claire een representante lijkt voor maatschappelijk betrokken advocaten, dan zul je denken dat zij niet alleen goed zal zijn in overtuigend argumenteren, maar ook dat zij haar afval wel zal scheiden en met het openbaar vervoer zal reizen. Overigens dient opgemerkt te worden dat dit soort selectiemechanismen geen bewuste strategieën zijn, maar onbewust en automatisch hun werk doen. Op basis van beschikbaarheid en representativiteit selecteren gaat vanzelf. Het risico van vliegreizen wordt over het algemeen veel hoger geschat dan het risico van autorijden, omdat vliegtuigongelukken in de media veel meer aandacht krijgen, terwijl het omgekeerd is: autorijden is veel riskanter. En verwoordt $u$ eens hardop uw eerste gedachten als $u$ een allochtoon in een gloednieuwe Mercedes ziet rijden. Je kunt je trainen in het uitsluiten van vooroordelen, in zo objectief mogelijk waarnemen en zeker in het alert zijn op dergelijke conclusies en het nemen van tegenmaatregelen, maar helemaal te vermijden zijn gekleurde waarnemingen en oordelen niet.

Op grond van die min of meer gekleurde selectie van informatie wordt dan een oordeel geveld of een beslissing genomen. Daarbij is ook een aantal systematische afwijkingen gevonden, alle te begrijpen vanuit onze beperkte cognitieve capaciteit - waar we nu eenmaal zuinig mee om moeten springen - en geen van alle bewust toegepast. De belangrijkste vertekeningen zijn bevestiging en conservatisme. Mensen hebben een fundamentele neiging informatie zodanig te wegen dat het hun gelijk bevestigt. Dat kost minder inspanning dan alles steeds opnieuw in twijfel trekken. Negatieve informatie is sowieso moeilijker mee te wegen: dat een sollicitante niet vermeldt dat zij het Engels beheerst, valt minder op dan dat zij een goede referentie meestuurt. Informatie die in tegenspraak is met je eigen opvattingen is minder beschikbaar, omdat je er liever niet op let. Het is overigens plausibel en over het algemeen wel zo efficiënt dat je niet geneigd bent steeds je eigen ongelijk aan te tonen. Conservatisme verwijst naar het fenomeen dat mensen vasthouden aan wat ze eenmaal zijn gaan geloven. Een eerste indruk is goud waard. Zo maken hulpverleners in de eerste momenten van contact een inschatting van hun cliënte en zij houden daar vervolgens aan vast, ook al krijgen zij later informatie die die inschatting onhoudbaar maakt (Arkes, 1981; Witteman, 1992).

Beslissende psychologen en psychotherapeuten zijn scherp onder vuur genomen, al hun missers zijn ze voor de voeten geworpen en hun pretenties als goede psychische hulpverleners zijn ontzenuwd (Dawes, 1994). De opvatting dat in de praktijk klinisch oordelen van hoge kwaliteit zou zijn, is onderuit gehaald. Klinisch oordelen blijkt net zo bevooroordeeld te zijn als elk ander soort oordelen; simplificerend, onbetrouwbaar, en makkelijk te vervangen door simpele statistische procedures (Caspar, 1997: Garb, 1998). Er is dan ook wel voorgesteld een robot-psychodiagnost te ontwikkelen, die op korte termijn de menselijke diagnost geheel zou kunnen vervangen (Kleinmuntz, 1994). Dat lijkt me slechts op heel beperkt gebied haalbaar en wenselijk. Het valt niet te ontkennen dat de beslisprocessen van hulpverleners en diagnosten vooroordelen en vertekeningen vertonen, en er zijn dan ook wel beslissingsondersteunende systemen ontwikkeld om clinici te helpen dergelijke fouten te vermijden (Van Aarle \& Van den Bercken, 1999; Witteman \& Kunst, 1999; Witteman 2003; Witteman \& Krol, in press). Maar het valt evenmin te ontkennen dat het werkterrein van psychodiagnosten zo slecht gestructureerd en onzeker is dat ook niet van ze verwacht kan worden dat zij volledig empirisch-analytisch te werk gaan (Witteman \& Kunst, 1997).

Er is overigens fundamentele kritiek mogelijk, én gegeven, op onderzoek uit deze 'heuristieken en biases' traditie (zie o.a. Van Dam, 1991). Ten eerste is onderzoek in 
die traditie vaak in het laboratorium uitgevoerd en betreft het meestal goktaken. Dat is beperkt en niet ecologisch valide. Ten tweede legt de grote aandacht voor de cognitieve incompetentie van beslissers eenzijdig de nadruk op de feilbaarheid van het menselijk oordeel, vanuit de gedachte dat je van fouten kunt leren. Die gedachte snijdt uiteraard hout. Anderzijds geeft zo'n fixatie op fouten een vertekend beeld van het menselijk oordeelsvermogen. In alledaagse situaties zijn we over het algemeen in staat flexibel en snel te oordelen en beslissen. Natuurlijk gaat het daarbij soms fout, maar evenzeer gaat het vaak goed. In plaats van kunstmatige situaties te creëren om beslissers er in te laten lopen, kun je met behulp van een 'process tracing' methode (Montgomery \& Svenson, 1989; Van Dam, 1993; Woods, 1993) proberen tot een beschrijving te komen van de vaardigheden waar beslissers in natuurlijke situaties over blijken te beschikken. Ook daarvan kun je leren over menselijke informatieverwerkingsprocessen. En een poging een beslishulp te ontwikkelen voor situaties die te ingewikkeld zijn om zonder hulp te overzien, bijvoorbeeld omdat er veel informatie uit verschillende bronnen moet worden gecombineerd en/of omdat de informatie onzeker en onvolledig is, zal zich moeten laten inspireren door de uitkomsten van zo'n descriptief onderzoek. Met de aansporing “u kunt er niets van; vanaf nu moet alles radicaal anders" win je geen medestanders; uitgaan van de feitelijk gehanteerde beslisstrategieën en constructieve tips en trucs aanreiken om die strategie, waar nodig en nuttig, te verbeteren, is een bij voorbaat kansrijker aanpak. De laatste jaren is onderkend dat er over beslissen méér te zeggen is dan dat mensen slecht presteren, als je hun beslisgedrag tegen een normatieve meetlat legt. Het blijkt dat mensen met snelle en zuinige ("fast\&frugal") beslisstrategieën in bepaalde situaties even accurate beslissingen kunnen nemen als met normatief correcte methodes (Gigerenzer, Todd \& the ABC research group, 1999). Of dat ook geldt voor diagnostische beslissingen is nog niet onderzocht. Daarnaast wint een 'naturalistische' aanpak terrein (Klein et al., 1993; Zsambok \& Klein, 1997). Daarin ligt de nadruk op een ander deel van het beslisproces dan dat waarin een bekend aantal opties tegen elkaar wordt afgewogen. Naturalisten bestuderen hoe beslissers in complexe, onzekere omstandigheden een inschatting maken van hun situatie, hoe ze een mentaal beeld van de situatie creëren, en hoe ze dan, gebruikmakend van hun ervaring, de meest plausibele, bij dat beeld passende beslissing nemen (Orasanu \& Connolly, 1993; Klein, 1997). Men wil er achter komen hoe beslissers feitelijk te werk gaan, om dat als uitgangs- en beginpunt te nemen voor verbetering (Cohen, Freeman \& Thompson, 1997).

Diagnosten zijn mensen, dus in hun beslissingen zijn alle genoemde heuristieken en biases aan te treffen. Maar met die constatering begrijpen we nog niet hoe diagnosten buiten experimentele situaties hun taak uitvoeren. Om dat te achterhalen lijkt ook voor de diagnostiek een naturalistische onderzoeksaanpak aangewezen. Dat impliceert niet een voorkeur voor een fenomenologische diagnostiek boven een nomologische. Want hoewel personen unieke individuen zijn, zijn oordelen op basis van statistische gegevens en evidence-based-beslissingen veel betrouwbaarder dan oordelen op basis van idiosyncratische theorieën. Bij statistische (of actuariële) oordeelsvorming worden gegevens mechanisch verwerkt, wordt kwantitatieve informatie met behulp van expliciete rekenregels gecombineerd, terwijl klinische predictie meer rekening zou kunnen houden met individuele bijzonderheden. De controverse tussen de klinische en statistische benadering werd in 1954 verwoord in een beruchte studie, waarin de statistische benadering het ruimschoots won van de klinische (Meehl, 1954). Uiteraard leidde dat in eerste instantie tot grote weerstand bij clinici. Maar de feiten konden niet worden ontkend, en de belangrijkste boodschap geldt onverkort, namelijk dat clinici niet kunnen volstaan met verwijzen naar een zesde zintuig of intuïtie, maar dat zij moeten kunnen aangeven waarop hun oordeel berust en dat hun afwegingen rationeel en mededeelbaar moeten zijn (zie ook Rispens, 1990). Voor onderzoekers betekent dit dat zij een onderzoeksaanpak dienen te volgen waarin het diagnosten mogelijk wordt gemaakt aan te geven hoe zij feitelijk beslissen: een naturalistische aanpak, kortom. Dus geen artificiële situaties om diagnosten te kunnen afrekenen op fouten in vergelijking met normatieve standaards, maar natuurlijke situaties waarin het beslisproces gevolgd kan worden, om zo te komen tot een beschrijvend model van de diagnostische besluitvorming. Dit laat onverlet dat de uiteindelijke diagnose uiteraard wel empirisch-wetenschappelijk moet zijn of worden onderbouwd.

\section{Verbeelding van de diagnostiek}

In de naturalistische aanpak geldt als uitgangspunt dat 'goed' of 'effectief' beslissen afhankelijk is van een complete en accurate representatie van het probleem (Lipshitz \& Ben Saul, 1997). De diagnostische besluitvorming begint met een repre- 
sentatie van de cliëntegegevens. lk verwacht dat we, met deze aanpak, zullen vinden dat diagnosten hun beslissing baseren op een representatie van de cliëntegegevens, die alle kenmerken heeft van een verhaal.

Ik heb het niet over de uiteindelijke diagnostische beslissing zelf, die vaak ook een verhaalvorm heeft. In een 'integratief beeld' wordt antwoord gegeven op de vragen, voor een specifieke cliënte: "Wat is er aan de hand?" en "Waardoor komt dit?" (De Bruyn et al., 1995; 2003). Zo'n diagnostisch verhaal komt tot stand na een actief proces van klacht- en probleemanalyse, waarna onderzoekshypothesen getoetst worden met behulp van onderzoeksmiddelen (tests en dergelijke). Dat is een ander verhaal dan mijn verbeelding van de diagnostiek. Mijn verbeelding is het beginpunt van het diagnostisch proces, het is de automatisch gegenereerde verhaalvormige representatie. Onderkennen en expliciteren van dit beginpunt zou, is mijn hoop en verwachting, kunnen zorgen voor de aansluiting tussen de natuurlijke wijze van diagnosticeren enerzijds en het volgen van een gestructureerde benadering zoals voorgeschreven in een hypothesetoetsend model als de diagnostische cyclus anderzijds. Het volgen van een hypothesetoetsend model gebeurt nu niet vanzelfsprekend. Net als beslissers op andere domeinen (vgl. Beach \& Lipshitz, 1993) ervaren ook diagnosten het volgen van zo'n prescriptief model als omslachtig en tijdrovend, hoewel men onderkent dat gestructureerder te werk gaan de kwaliteit van het diagnostisch proces zeker ten goede zou komen. Een aantal jaren geleden werd dit op een studiedag van orthopedagogen in discussie over diagnostiek (zie Van Aarle et al., 1996) nog geconstateerd. Het hypothesetoetsende model bleek bij velen het gevoel op te roepen van een keurslijf. Het gedwongen worden tot vaste volgordes van analyse-activiteiten leek het de diagnost erg moeilijk te maken informatie te integreren. De boven beschreven resultaten van onderzoek naar menselijk beslissen maken duidelijk waarom het voor mensen net zo onmogelijk is informatie niet in een context of kader te zien als om niet opzij te springen voor een aanstormende auto. Het is de bijdrage niet van de klassieke maar van de naturalistische benadering in de besliskunde dat is aangetoond dat het voor het begrijpen hoe mensen beslissen wezen lijk is te bestuderen hoe zij de context waarin zij beslissen opvatten. Hoe die context of dat 'frame' er uitziet zal afhangen van de ervaring en expertise van de diagnost, maar dat er direct een representatie van de cliëntegegevens gevormd zal worden is eigenlijk vanzelfsprekend. Die representatie, dat situatiemodel, is dan het begin van het diagnostische proces, het verhaal achter het genereren en toetsen van verklaringen voor het probleemgedrag.

\section{Beeldverhalen}

Waar het gaat om het beslissen op basis van of over gedrag van anderen, zoals in de psychodiagnostiek, hebben situatiemodellen vaak een verhaalvorm. Een verhaal is een coherent scenario of 'narrative', een vertelling, waarin een serie gebeurtenissen temporeel en causaal geordend is (Hastie \& Dawes, 2001). Van "Er was eens" via "en toen" en "en daarom" tot "en dus". Een verhaal wordt vrijwel automatisch geconstrueerd, om de beschikbare feiten te ordenen. Het bevat één of meer episodes, elk met één of meer actoren, met een initiërende gebeurtenis, met doelen, handelingen en gevolgen en met daarmee gepaard gaande mentale toestanden van de actor of ac toren, in een causale configuratie (Pennington \& Hastie, 1988). We begrijpen een gebeurtenis pas echt als we haar in een dergelijk verhaal kunnen plaatsen. Het verhaal is gebaseerd op algemene kennis over menselijk handelen en de aanleidingen en gevolgen daarvan en op analogieën met eerder ervaren gebeurtenissen (Pennington \& Hastie, 1986). Bij het nemen van beslissingen fungeert zo'n verhaal als een samenvattende representatie van de situatie tussen de gegevens en de beslissing. Er worden verklaringen in gegeven van menselijk handelen in termen van omstandigheden en van motieven, doelen en intenties (Hastie \& Pennington, 2000). Zo slaan we ook onze ervaringen op; het verhaal is het cognitieve formaat dat we gebruiken om het verleden samen te vatten en te projecteren naar de toekomst en om anderen en onze situatie te begrijpen (Schank \& Abelson, 1995).

Het verhaalmodel is geïntroduceerd (Pennington \& Hastie, 1986; 1988; en gesimuleerd in een computermodel door Gaines, Brown \& Doyle, 1996) om in de rechtspraak jurybeslissingen te verklaren. Men bevond dat een samenvatting van bewijsmiddelen en getuigenissen in een rechtszaak gegeven werd in de vorm van een verhaal, en dat de beslissing op dit verhaal gebaseerd was, en niet direct op de bewijsmiddelen. De onderzoekers voorzagen de toepasbaarheid van deze interim-representatie in andere beslissingsgebieden met een grote hoeveelheid ongeordende en heterogene informatie, die betrekking heeft op gemotiveerd menselijk gedrag. In een onderzoek waarin onder andere bij een psychiater een diagnostisch protocol werd afgenomen, bleek de onderbouwing van de diagnose inderdaad een duidelijke ver- 
haalstructuur te hebben (Patel, Arocha \& Groen, 1987). Via een analogieredenering verwacht $i k$ verhalen te vinden in protocollen van psychodiagnosten. Ik verwacht dat diagnosten zo'n samenvattende representatie zullen construeren, en dat zij hun diagnose hierop zullen baseren, en niet op ongeïnterpreteerde cliëntegegevens. Problemen die individuen betreffen, zoals cliënten bij een diagnost, roepen bij beslissers als vanzelf causaal (of epistemisch) redeneren op (Nisbett et al., 1983; Beach, 1992). Op basis van informatie over de cliënte, ervaring met vergelijkbare gevallen en theoretische kennis zal de diagnost zich de cliënte verbeelden middels een verhaalvormige representatie (vgl. Pennington \& Hastie, 1993).

\section{Kenmerken en constructie van verhalen}

Een psychodiagnostisch verhaal verwijst naar een theorie of model met causale regels, die geïnstantieerd worden met gebeurtenissen in het leven van de cliënte (vgl. Hastie \& Dawes, 2001); het bevat een temporele en causale ordening van de cliëntegegevens en is coherent en consistent.

Causaliteit is het eenduidigst toepasbaar op fysieke veroorzaking. In de natuurlijke wereld wordt $A$ begrepen als de oorzaak van $B$ als uit natuurwetten volgt dat als $A$ optreedt, B volgt. In de menselijke wereld kunnen gebeurtenissen ook gedrag veroorzaken, maar er zijn vooralsnog geen onomstreden gedragswetten voor dergelijke causale relaties. We kunnen wel spreken over gedragscausaliteit van gebeurtenis A en gedrag $B$, als we dat begrijpen als contingent en constant samengaan (conjunctie) van A en B. De test voor de validiteit van zo'n gedragscausale verklaring zou zijn om 'tegenfeitelijk' (contrafactisch) te redeneren (Mackie, 1965): van een gebeurtenis kan gezegd worden dat die de oorzaak is van bepaald gedrag als, wanneer de gebeurtenis niet was opgetreden, het gedrag zich ook niet zou hebben voorgedaan.

Bijvoorbeeld: rouwen om het verlies van een geliefde wordt veroorzaakt door het verlies van die geliefde; zonder dat voorafgaande verlies zou het huidige rouwgedrag niet zijn voorgekomen. In feite is het voor veel gedrag vrijwel onvoorstelbaar dat het het resultaat zou zijn van één enkele geïsoleerde gebeurtenis; vaak is er sprake van een samenloop van gebeurtenissen en omstandigheden. In psychodiagnostische verklaringen dient de beweerde gedragsoorzakelijke relatie ondersteund te worden door te verwijzen naar een theorie die die relatie verklaart. Daarbij moet overigens zeer kritisch worden gekeken naar de geopperde oorzaken, omdat blijkt dat causale verklaringen soms meer zeggen over de theoretische oriëntatie van de diagnost dan over de cliënte (Garb, 1998; Witteman \& Koele, 1999).

Een coherent verhaal is er één waarin alle elementen zijn verbonden aan de centrale vraag 'wat is er aan de hand met deze cliënte?'. Er zijn geen losse eindjes, en de afwezigheid van losse eindjes kenmerkt over het algemeen accurate beslissingen (Patel \& Ramoni, 1997). Alle elementen die een cliënte kenmerken, passen in het verhaal en het verhaal is compleet, er zijn geen leemtes in de structuur (Thagard, 1989). De theorie levert de context, dat wil zeggen een uitleg waarom de cliënte zich op deze bepaalde manier heeft moeten ontwikkelen. Als de theorie zo'n plausibel verhaal niet toelaat, dan bevat het verhaal dubbelzinnigheden (vgl. Wagenaar, Van Koppen \& Crombag, 1993). Consistent betekent dat het verhaal geen tegenstrijdige conclusies toelaat, en dat het geen elementen bevat die elkaar tegenspreken. Verhalen, psychodiagnostisch of anders, vertonen idealiter wèl maar in feite misschien niet al deze kenmerken. Zeker de beeldverhalen die ik bedoel, de automatisch gegenereerde representaties van de situatie van de cliënte, zullen mankementen vertonen. Toch zullen deze kenmerken duidelijk in een protocol herkenbaar aanwezig moeten zijn, wil men van diagnosten kunnen beweren dat zij een verhaal construeren.

Kortom, verhalen construeren is een automatisch werkzame cognitieve capaciteit. (gebaseerd op Pennington \& Hastie 1986; 1988). Als we informatie krijgen aangeboden, construeren we vanzelf zo'n verhaal, een gestructureerde representatie die coherentie geeft aan de gepresenteerde informatie en die afleidingen toestaat ove redenen voor gebeurtenissen in het verleden en voorspellingen over gebeurtenissen in de toekomst, die zich ofwel natuurlijk voordoen of als gevolg van interventie (Hastie \& Dawes, 2001). We gebruiken daarbij onze causale kennis. Die causale kennis is gerepresenteerd in voorbeeldverhalen die in ons geheugen zijn opgeslagen (Schank \& Abelson, 1995). Zulke voorbeeldverhalen kan men 'prototypenarratieven' noemen (in de sociale psychologie noemt men ze impliciete theorieën) - en daar hebben experts vanzelfsprekend een grotere en verfijnder ontwikkelde voorraad van dan niet-experts (Hastie \& Dawes, 2001). Het voor de huidige situatie invullen van zo'n voorbeeldverhaal, oftewel het creëren van een situatiemodel, is een wezenlijk onderdeel van elke besluitvorming (Klein, 1997), dus ook de diagnostische. 


\section{Elicitatie van diagnostische representaties}

Of diagnosten zich daadwerkelijk hun cliënten in verhaalvorm verbeelden, kan achterhaald worden door protocollen van het proces te verzamelen en die te analyseren. Methoden om aan protocollen van het diagnostisch proces te komen zijn Cognitieve Taak Analyse (Gordon \& Gill, 1997) of Cognitieve Structuur Analyse (Leddo \& Cohen, 1989). Met behulp van gestructureerde en ongestructureerde interviews, 'free recall' van een gepresenteerde casus (Patel \& Ramoni, 1997) of hardop denken tijdens het beslisproces (Ericsson \& Simon, 1993,Van Someren, Barnard \& Sandberg, 1994) kan achterhaald worden hoe het mentale model van de diagnost die een diagnostische beslissing neemt, er uit ziet. Daarbij zal men erop verdacht moeten zijn de elicitatiemethode aan te passen aan de manier waarop diagnosten hun taak normaal gesproken uitvoeren, zodat zij de voorgelegde taak niet als wezensvreemd ervaren en op een vertrouwde manier antwoorden kunnen geven (vgl. Renooij \& Witteman, 1999; Witteman \& Renooij, 2003). Ook moet men erop verdacht zijn dat experts vaak veel procedurele kennis hebben geautomatiseerd en dat men die kennis dus niet terug zal vinden in het protocol van hun beslisproces. Men kan dan achteraf de diagnost vragen de leemtes op te vullen of men neemt protocollen af van gevorderde diagnosten in plaats van van experts.

Analyse van die protocollen (Newell \& Simon, 1972) moet dan duidelijk maken of diagnosten inderdaad een verhaal vertellen. Een methode kan zijn: de protocollen analyseren met een "verhaalgrammatica" (Rumelhart, 1975). Zo'n grammatica bestaat uit een verzameling syntactische regels en een bijbehorende verzameling semantische interpretatieregels, die gebruikt kunnen worden om de structuur die onder een tekst ligt te analyseren, dus om te bepalen of een rij zinnen inderdaad een verhaal vormt. Een andere methode kan zijn: een informele of substantiële logische analyse op het protocol toepassen (Bromley, 1986; zie ook Krause \& Clark, 1993). Je begint bij de conclusie en verbindt de andere tekstfragmenten daar achtereenvolgens aan. Dan kun je een diagram opstellen dat de onderliggende logica weergeeft. Wil zo'n diagram een verhaal identificeren, dan moet het een causale en temporele ordening laten zien en geheel samenhangend zijn.

\section{Vertekende verhalen}

Als blijkt dat diagnosten inderdaad, zoals verwacht, een verhaal vertellen, dan zijn de rechtvaardigingen van hun beslissing duidelijk en begrijpelijk door naar dat verhaal te verwijzen. Dat is een groot voordeel. Maar er zijn uiteraard ook nadelen aan het gemak waarmee mensen verhalen construeren om gebeurtenissen te begrijpen. Je zult bijvoorbeeld meestal maar één verhaal construeren. Misschien overweeg je alternatieve versies van delen van het verhaal, maar zelden gehele alternatieve verhalen; dat zou cognitief te belastend zijn. Het risico is dan dat selectief met gegevens wordt omgegaan of dat gegevens verdraaid worden om in het verhaal te passen. Je kunt dan ook de waarschijnlijkheid overschatten dat dat ene verhaal het juiste is. Je concentreert je op dat ene verhaal, en construeert geen bredere, meer systematische representatie van de beslissingssituatie (Hastie \& Dawes, 2001). Tenslotte is het onwaarschijnlijk dat je ervaring gehad zult hebben met alle mogelijke situaties en alle mogelijke verklaringen van situaties, dus je hebt een onvolledige verzameling voorbeeldverhalen om uit te putten.

Om diagnosten te behoeden voor bevooroordeelde beslissingen mag het automatisch gegenereerde, initiële verhaal dus niet zonder meer geaccepteerd worden. De essentie van de empirische cyclus, te weten het toetsen van diagnostische hypothesen, dient wel degelijk gehandhaafd te worden. Het initiële verhaal moet dus als hypothese worden opgevat. Die dient dan getoetst te worden aan informatie die onafhankelijk is van de informatie waarop het initiële verhaal is gebaseerd. Diagnosten moeten gestimuleerd worden hun eigen verhaal kritisch te bekijken en te proberen alternatieve verhalen op te stellen. Dat kan bijvoorbeeld door 'critiquing', het toetsen van het verhaal op drie punten: compleetheid, dat wil zeggen dat alle informatie die nodig is om de conclusie te trekken in het verhaal aanwezig is; afwezigheid van conflict, dat wil zeggen dat er geen nieuwe argumenten te geven zijn waarvan de conclusies in tegenspraak zijn met de conclusie van bestaande argumenten; en betrouwbaarheid, dat wil zeggen niet gebaseerd op twijfelachtige assumpties (Cohen, Freeman \& Thompson, 1997). Ook kan geïndividualiseerde, computergebaseerde training gebruikt worden, bijvoorbeeld een simulatieprogramma (Mross \& Roberts, 1992; gebaseerd op het constructie-integratiemodel van Kintsch, 1998) om diagnosten te leren hoe ze coherente conceptuele modellen van hun cliënten kunnen opstellen. 


\section{Resumerend}

Prescriptieve modellen van het psychodiagnostische besluitvormingsproces zijn nodig omdat van diagnosten niet verwacht kan worden dat zij zonder hulp alle informatie en de implicaties daarvan kunnen overzien en goed gefundeerd kunnen beslissen. Daarvoor is hun taak te slecht gestructureerd en onzeker. Structureren van het proces voorkomt idiosyncrasie en komt cliënten ten goede. Maar als prescripties het onmogelijke vragen van de diagnost, zoals niet letten op opvallende gegevens en klachten en problemen niet in een kader zien, dan is de mogelijkheid ze te volgen op voorhand al beperkt. Succesvolle ondersteuning van het beslisproces, met computergebaseerde systemen of met een voorgeschreven volgorde van logische stappen, werkt niet als mensen gedwongen worden een manier van redeneren te volgen waar ze niet vertrouwd mee zijn (Cohen, 1993). Kans op succes is groter naarmate meer rekening wordt gehouden met de manier waarop de beslisser bij voorkeur tewerk gaat. Mensen maken een representatie van hun beslisprobleem, diagnosten van hun cliënte. Als die representatie, zoals ik verwacht, goed beschreven kan worden als 'verhaal', dan moet er in de prescripties ruimte zijn voor het construeren van zo'n verhaal en vooral ook hulp bij het toetsen van de geldigheid van het verhaal. Zie het verhaal als hypothetisch antwoord op de vraag "wat is er aan de hand met deze cliënte?" en toets deze hypothese vervolgens.

Dat wil zeggen dat ik ervoor pleit meer rekening te houden met de verbeelding van de diagnost. Dat wil zeker niet zeggen dat ik de klinische intuïtie in ere zou willen herstellen. Onderbouwingen van diagnoses met argumenten als 'dat voel ik zo' of 'ik weet dat uit ervaring' zijn ten enen male onvoldoende. Wat ik voorsta is geen fenomenologische benadering, niet het "schilderen van een psychologisch portret" (Rispens \& Schoorl, 1991), geen impressionistische werkwijze. Ik pleit voor een aanvulling op de empirisch-analytische benadering met een beter begrijpen van de stap van het genereren van diagnostische hypothesen, waarbij die stap naar verwachting bestaat uit de constructie van een verhaal op basis van de cliëntegegevens. Mijn hoop is dat door deze diagnostische verbeelding te integreren in de diagnostische cyclus het bezwaar vervalt dat die cyclus te onnatuurlijk zou zijn. Daarmee zal de bruikbaarheid van de cyclus in de praktijk vergroot worden, waarmee de psychodiagnostiek en de cliënten gebaat zijn.

\section{Dankwoord}

Ik sluit af met enkele woorden van dank.

Lieve ouders, Piet en Biebeth: wie van ons had vroeger van dit moment durven dromen? Als waar lid van de protestgeneratie was ik vroeger overal tegen. Tegen het establishment, tegen de oorlog in Vietnam, en tegen alles wat jullie hadden opgebouwd. Studeren, werken: dat deden 'losers' - wij zouden eerst wel eens de wereld verbeteren. Dat was, mogen we nu constateren, nogal tamelijk overmoedig. Maar zeker is dat ik in ieder geval nooit gedacht had dat ik ooit nog eens een inaugurele rede zou houden, en daar nog trots op zou zijn ook. Jullie opvoeding heeft in ieder geval dus geen blijvende stoornis opgeleverd in mijn leergierigheid of mijn ambities. Misschien in tegendeel; misschien dat jouw, toen behoorlijk irritante manier van antwoorden op mijn vragen, Piet, namelijk steevast "Wat denk je er zelf van?" de basis gelegd heeft voor een wetenschappelijke manier van leven en ervaren, die nu dan bekroond is. Wie zal het zeggen? Ik dank jullie in ieder geval voor jullie grote bijdrage aan mijn zelfvertrouwen en voor alle ruimte die jullie me gelaten hebben het zelf uit te zoeken.

Een constante factor en een onvoorwaardelijk maatje in de strijd het leven naar onze wensen te plooien, is mijn favoriete zus Eva. Zo verschillend als we zijn Eva, zo belangrijk ben je voor me - altijd geweest, en nog. We hebben samen of via elkaar heel wat beleefd. We hebben andere keuzes gemaakt, we zijn in verschillende situaties terecht gekomen, maar je blijft toch altijd dichtbij. Ik dank je van harte, Eva, dat je me altijd geaccepteerd hebt, wat ik ook voor rare streken uithaalde. De ruggensteun waarvan ik weet dat je me die altijd zult geven, maakt me sterk. Dat is me onzegbaar veel waard.

Ik kan niet alle hoofdrolspeelster en spelers in mijn leven opnoemen en bedanken maar noem de belangrijkste. Maarten Coolen, mijn scriptiebegeleider, dreef me doo zijn perfectionisme tot wanhoop maar ook wetenschappelijke nauwkeurigheid.

Rob Stobberingh dank ik, omdat hij me durfde aannemen bij Psychonomie, ondanks zijn huiver voor vrouwelijke stafleden. Harald Kunst, René van Hezewijk, Geert Panhuysen en Maarten van Son met de depressiegroep waren onontbeerlijk bij het tot stand komen van mijn proefschrift. Pieter Koele, je wordt bedankt dat je me, nu al jarenlang, trouw vaak meermalen daags per e-mail stoort, me met een "zo ken ik je weer" een hart onder de wetenschappelijke riem steekt, en het daarbij gelukkig 
ook niet schuwt je in een moeite door met mijn privé-zielenheil te bemoeien. Jürgen van den Berg dank ik dat hij me naar Informatiekunde haalde, waar het met de enthousiaste groep, inclusief Lex Bijlsma, uiterst prettig werken was, vooral dank zij Robbert-Jan Beun en Rogier van Eijk, en prettig productief met Silja Renooij en andere leden van de Decision Support-groep. Wiebe van der Hoek speelde een belangrijke rol in mijn vertrek uit Utrecht: ik moest het doen, hoogleraar worden in Nijmegen, want hij werd zelf hoogleraar in Liverpool, dus waarom zou ik dan nog in Utrecht blijven? Gelukkig is het ons gelukt ondanks de afstand goede vriendjes te blijven, die de lasten en lusten delen van nieuwe wetenschappelijke verantwoordelijkheden en nieuwe privé-situaties. Dank voor je trouw, Wiebe. Petra van Roon is sinds onze gezamenlijke studietijd bij Wijsbegeerte nog steeds mijn beste vrien din. Het is fijn zo in elkaars leven te delen. Mijn slappe verhaaltjes ter verdediging van onverwachte keuzes, van inconsistent gedrag of vreemde gedachtenkronkels bevraag je kritisch, zonder me het idee te geven dat ik niet deug. Dat is me heel wat waard, Petra! Weinigen waren zo oprecht blij toen ik hoogleraar werd als Rob Lith, die me ondanks uiteenlopende keuzes in het leven nog steeds na aan het hart ligt. Voor de onontbeerlijke afleiding dank ik mijn bridgemaatjes, Geert Blom, Rudi Karemaker en Fred de Kerf, en m'n sportieve maatjes Jos Scheurink, Bas Beljaars, René Verheul, en, met onderbrekingen, Wilmar Schaufeli. Elseline Hoekzema is een van de hoekstenen van ons gezinnetje. Ik kan me mijn afleidingen permitteren; de meiden zijn zo dol op jou dat ze me daartoe vaak zelfs aansporen. Ik hoop dat je nog lang dat deel van mijn zorg voor ze blijft delen. Jaap Verkerk dank ik omdat hij niets wilde horen van aarzelingen of $i k$ het wel zou kunnen, prof worden en voor de manier waarop hij dat duidelijk maakte. De diagnostiekgroep in Nijmegen, met John van den Bercken, Edward van Aarle en Nicole Krol, ben ik zeer erkentelijk voor de hartelijke en open ontvangst in jullie midden. Huub Pijnenburg stuurde me een prachtig boeket bij mijn benoeming en fleurde mijn eerste werkdag op met een rode roos. Huub: mijn meest gewaardeerde collega van de overkant. Henk Jan Lebbink, Erwin van Geenen en Leontien de Kwaadsteniet: enerzijds hoop ik dat jullie snel en goed promoveren, anderzijds dat jullie nog lang mijn partners in de wetenschap blijven. Met Eric De Bruyn verloopt de samenwerking zo prettig, dat het me eigenlijk vreselijk spijt dat ik je opvolg Eric, en dat je niet nog lange jaren mijn collega zult blijven. Het besturen van Gezin\&Gedrag met Rutger Engels is erg prettig en lekker efficiënt, en onderwijszaken regelen met Jan Janssens is een groot genoegen. Dank jullie allen, en uiteraard ook de dames van het secretariaat Ans de Wit en Hedwig Lahnstein en alle andere niet met name genoemde collega's, voor jullie hartelijke collegialiteit. Ook de niet met name genoemde vriendinnen, vrienden en familieleden dank ik voor jullie rol in mijn leven. Het Stichtingsbestuur en het College van Bestuur van de Katholieke Universiteit Nijmegen en de decaan en het bestuur van de faculteit Sociale Wetenschappen dank ik voor het in mij gestelde vertrouwen.

Mijn belangrijkste inspiratiebron en levenslotgenoten heb ik tot het laatst bewaard: mijn fantastische dochters Valentijn en Ino. Jullie zitten hier terecht op de voorste rij, zoals jullie in mijn leven ook op de voorste rij zitten. Jullie hebben 't niet altijd makkelijk met jullie concurrent om mijn aandacht, m'n professoraat in het Nijmeegse. Jullie moeten mijn chagrijn aanhoren als vergaderingen zinloos laat en lang duren of als studenten eerst vragen en dan pas nadenken. Vooral op vrijdagavond, als we alle drie moe zijn van de week, maken we lekker ruzie, gelukkig meestal om dat dan snel weer goed te knuffelen. Jullie zijn de besten, meiden. Ik geniet elke dag opnieuw van je fantasie, Ino, en van je veelzijdigheid, Valentijn en van jullie beider creativiteit, leergierigheid, muzikaliteit en geestelijke lenigheid. Ik hoop dat jullie mijn verhaal konden volgen; ik draag het in ieder geval bij deze aan jullie op. Dat ik ontzettend veel geluk heb met jullie, dat is zeker niet alleen mijn verbeelding, maar mijn stellige diagnostische besluit.

Ik heb gezegd. 


\section{Referenties}

Arkes, H.A. (1981). Impediments to accurate clinical judgment and possible ways to minimize their impact. Journal of consulting and clinical psychology, 49(3), 323-330. Baron, J.(1995). Thinking and deciding. Cambridge University Press.

Beach, L.R. (1992). Epistemic strategies: causal thinking in expert and nonexpert judgment. In G. Wright \& F. Bolger (Eds.), Expertise and decision support (pp. 107-127) New York: Plenum Press.

Beach, L.R. \& Lipshitz, R. (1993). Why classical decision theory is an inappropriate standard for evaluating and aiding most human decision making. In G.A. Klein, J. Orasanu, R. Calderwood \& C.E. Zsambok (Eds.), Decision making in action: models and methods (pp. 21-35). Norwood, NJ: Ablex Publishing.

Bromley, D.B. (1986). The case-study method in psychology and related disciplines.

Chichester: Wiley.

Carlier, E. \& Schoorl, P.M. (1990). Het diagnostisch proces in model. In J. Rispens,

E. Carlier \& P. Schoorl (Red.), Diagnostiek in de hulpverlening: methodische aspecten

(pp. 57-76). Amsterdam: Swets \& Zeitlinger.

Caspar, F. (1997). What goes on in a psychotherapist's mind? Psychotherapy Research, 7(2), 105-125.

Cohen, M.S. (1993). The bottom line: naturalistic decision aiding. In G.A. Klein,

J. Orasanu, R. Calderwood \& C.E. Zsambok (Eds.), Decision making in action:

models and methods (pp. 265-269). Norwoord, NJ: Ablex.

Cohen, M.S., Freeman, J.T. \& Thompson, B.B. (1997). Training the naturalistic decision maker. In C.E. Zsambok \& G. Klein (Eds.), Naturalistic decision making (pp. 257-268). Mahwah, NJ: Lawrence Erlbaum Associates.

Dawes, R.M. (1994). House of cards: psychology and psychotherapy built on myth. New York: Free Press.

De Bruyn, E.E.J. (1992). A normative-prescriptive view on clinical psycho-diagnostic decision making. European Journal of Psychological Assessment, 8, 163-171. De Bruyn, E.E.J., Pameijer, N.K., Ruijssenaars, A.J.J.M. \& Van Aarle, E.J.M. (1995).

Diagnostische besluitvorming: handleiding bij het doorlopen van de diagnostische cyclus. Leuven: Acco.

De Bruyn, E.E.J., Pameijer, N.K., Ruijssenaars, A.J.J.M. \& Van Aarle, E.J.M. (2003). De diagnostische cyclus: een praktijkleer. Leuven: Acco.
De Groot, A.D. (1946). Het denken van den schaker. Amsterdam: Noord-Hollandsche Uitg. Mij.

De Groot, A.D. (1961). Methodologie. Den Haag: Mouton.

Denig, P., Witteman, C.L.M. \& Schouten, H.W. (2002). Scope and nature of prescribing decisions made by general practitioners. Quality and Satefy in Health Care, 11, 137-143. Derksen, J.J.L. (2001). Descriptieve en structurele psychodiagnostiek. Nijmegen:

Pen tests publisher b.v.

Doerbecker, C. (1985). Interpreteren een methodologisch dilemma? In R. Lubbers

(Red). Hermeneutische diagnostiek en probleemoplossing: de mens als tekst (pp. 31-51). Nijmegen: Dekker \& van de Vegt.

Ericsson, A., \& Simon, H.A. (1993). Protocol analysis: verbal reports as data. Cambridge, MA: The MIT Press.

Evans, J.St.B.T. (1989). Bias in human reasoning: causes and consequences. Hove and London, UK: Lawrence Erlbaum Associates.

Garb, H.N. (1998). Studying the clinician: judgment research and psychological assessment. Washington, DC: American Psychological Association.

Gaines, D.M., Brown, D.C. \& Doyle, J.K. (1996). A computer simulation model of juror decision making. Expert systems with applications, 11(1), 13-28.

Gigerenzer, G., Todd, P.M. \& the ABC research group (1999). Simple heuristics that make us smart. Oxford University Press.

Gordon, S.E. \& Gill, R.T. (1997). Cognitive Task Analysis. In C.E. Zsambok \& G. Klein (Eds.), Naturalistic decision making (pp. 131-140). Mahwah, NJ: Lawrence Erlbaum Associates.

Hastie, R. \& Dawes, R.M. (2001). Rational choice in an uncertain world: the psychology of judgment and decision making. Thousand Oakes, London: Sage Publications. Hastie, R. \& Pennington, N. (2000). Explanation-based decision making. In T. Connolly, H.R. Arkes \& K.R. Hammond (Eds.), Judgment and decision making: an interdisciplinary reader (2nd ed) (pp. 212-228). Cambridge, UK: Cambridge University Press. Kievit, Th., Tak, J.A. \& Bosch, J.D. (Red.)(2002). Handboek psychodiagnostiek van de hulpverlening aan kinderen. Utrecht: de Tijdstroom.

Kintsch, (1998). Comprehension: a paradigm for cognition. Cambridge, Ma: Cambridge University Press.

Klein, G. (1997). The recognition-primed decision model: looking back, looking 
forward. In In C.E. Zsambok \& G. Klein (Eds.), Naturalistic decision making (pp. 285292). Mahwah, NJ: Lawrence Erlbaum Associates.

Klein, G.A., Orasanu, J., Calderwood, R. \& Zsambok, C.E. (Eds.)(1993). Decision making in action: models and methods. Norwoord, NJ: Ablex.

Kleinmuntz, B. (1994). Toward intelligent computerized clinicians. Computers in

human behavior, 10, 457-466.

Krause, P. \& Clark, D. (1993). Representing uncertain knowledge. Oxford, UK: Intellect. Krol, N.P.C.M., De Bruyn, E.E.J. \& Van den Bercken, J.H. (1992). Diagnostic classification by experts and novices. Acta Psychologica, 81, 23-37.

Leddo, J.M. \& Cohen, M.S. (1989). Cognitive structure analysis: a tool for eliciting the structure and content of expert knowledge. IEEE Proceedings of Al in Government, 275-280

Lipshitz, R. \& Ben Shaul, O. (1997). Schemata and mental models in recognitionprimed decision making. In C.E. Zsambok \& G. Klein (Eds.), Naturalistic decision making (pp. 293-303). Mahwah, NJ: Lawrence Erlbaum Associates.

Loomes, G. \& Sugden, R.(1982). Regret theory: an alternative theory of rational choice under uncertainty. Economic Journal, 92, 805-824.

Lubbers, R. (red).(1985). Hermeneutische diagnostiek en probleemoplossing: de mens als tekst. Nijmegen: Dekker \& van de Vegt.

Mackie, J.L. (1965). Causes and conditions. American philosophical quarterly, 2, 245-264.

Meehl, P.E. (1954). Clinical versus statistical prediction. Minneapolis: University of Minnesota Press.

Montgomery, H. \& Svenson, O. (Eds.)(1989). Process and structure in human decision making. London: Wiley.

Mross, E. \& Roberts, J. (1992). The construction integration model: a program and a manual. Technical report ICS, no 92-14. Boulder, Co: Institute for cognitive science, University of Colorado.

Newell, A., \& Simon, H.A. (1972). Human problem solving. Englewood Cliffs, NJ: Prentice Hall.

Nisbett, R.E. \& Ross, L. (1980). Human inference: strategies and shortcomings of social judgment. Englewood Cliffs, NJ: Prentice Hall.

Nisbett, R.E., Krantz, D.H., Jepson, C., \& Kunda, Z. (1983). The use of statistical heuristics in everyday inductive reasoning. Psychological Review, 90, 339-363. Orasanu, J. \& Connolly, T. (1993). The reinvention of decision making. In G.A. Klein, J. Orasanu, R. Calderwood \& C.E. Zsambok (Eds.), Decision making in action: models and methods (pp. 3-20). Norwoord, NJ: Ablex.

Patel, V.L., Arocha, J.F. \& Groen, G.J. (1987). Domain specificity and knowledge utilization in diagnostic explanation. Proceedings of the ninth annual conference of the Cognitive Science Society, 187-202.

Patel, V.L. \& Ramoni, M.F. (1997). Cognitive models of directional inference in expert medical reasoning. In P.J. Feltovich, K.M. Ford \& R.R. Hoffman (Eds.), Expertise in context: human and machine (pp. 67-99). Cambridge, MA: The MIT Press.

Pennington, N., \& Hastie, R. (1986). Evidence evaluation in complex decision making. Journal of personality and social psychology, 51(2), 242-258.

Pennington, N., \& Hastie, R. (1988). Explanation-based decision making: effects of memory structure on judgment. Journal of experimental psychology: learning, memory, and cognition, 14(3), 521-533.

Pennington, N., \& Hastie, R. (1993). A theory of explanation-based decision making In: G.A. Klein et al. (Eds.), Decision making in action: models and methods (pp. 188201). Norwood, NJ: Ablex

Renooij, S. \& Witteman, C.L.M. (1999). Talking probabilities: communicating probabilistic information with words and numbers. International Journal of Approximate Reasoning, 22, 169-194.

Rispens, J. (1990). Diagnostiek in de hulpverlening: een probleemverkenning. In J. Rispens, E. Carlier \& P. Schoorl (Red.), Diagnostiek in de hulpverlening: methodische aspecten (pp. 23-40). Amsterdam: Swets \& Zeitlinger.

Rispens, J. \& Schoorl, P.M. (1991). Professionele pedagogische hulpverlening. Pedagogisch Tijdschrift, 16, 161-177.

Rumelhart, D.E. (1975). Notes on a schema for stories. In D.G. Bobrow \& A. Collins

(Eds.), Representation and understanding: studies in cognitive science (pp. 211-236) New York: Academic Press.

Schank, R.C., \& Abelson, R.P. (1995). Knowledge and memory: the real story. In R.S.

Wyer jr (Ed.), Advances in social cognition, vol VIII (pp. 1-85). Hillsdale, NJ: Lawrence Erlbaum Associates.

Snoek, J.W. (1989). Het denken van de neuroloog. Groningen: Dijkhuizen van Zanten. 
Ter Laak, J.J.F. (1995). Psychologische diagnostiek: inhoudelijke en methodologische grondslagen. Amsterdam/Lisse: Swets \& Zeitlinger.

Ter Laak, J.J.F. \& De Goede, M. (2003). Psychologische diagnostiek: inhoudelijke en methodologische grondslagen. Amsterdam/Lisse: Swets \& Zeitlinger.

Thagard, P. (1989). Explanatory coherence. Behavioral and brain sciences, 3, 435-502. Tversky, A. \& Kahneman, D. (1974). Judgement under uncertainty: heuristics and biases. Science, 185, 1124-1131.

Van Aarle, E.J.M. Carlier, E., Van der Aalsvoort, G.M. \& Kosterman, W.M. (Red.) (1996) Diagnostiek in beweging: weging van context of door context bewogen? Leuven/Amersfoort: Acco.

Van Aarle, E.J.M. \& Van den Bercken, J.H.L. (1999). The development of a knowledgebased system supporting the diagnosis of reading and spelling problems (II). Computers in human behavior, 15, 693-712.

Van Dam, K. (1991). Fixatie op fouten: kunnen mensen beslissen? Amsterdam: Swets \& Zeitlinger.

Van Dam, K. (1993). Beoordelingsprocessen: structuur- versus procesgericht onderzoek. In P. Koele \& J. van der Pligt (Red.), Beslissen en beoordelen (pp. 156-180). Amsterdam: Boom.

Van Someren, M.W., Barnard, Y \& Sandberg, J. (1994) The think aloud method a practical approach to modelling cognitive processes, London: Academic Press. Van Strien, P.J. (1984). Naar een verwetenschappelijking van de praktijk. Tijdschrift voor Orthopedagogiek, 162-180.

Van Strien, P.J. (1985). Intepretatieprocessen in de psychologische en agogische praktijk. In R. Lubbers (Red.), Hermeneutische diagnostiek en probleemoplossing: de mens als tekst. (pp. 126-144). Nijmegen: Dekker \& van de Vegt.

Vertommen, H. (2002). Klinische psychodiagnostiek. Leuven: Acco.

Vertommen, H., Ter Laak, J. \& Bijttebier, P. (2002). Het diagnostisch proces.

Diagnostiek-wijzer, 5(1), 4-16.

Wagenaar, W.A., Van Koppen, P.J. \& Crombag, H.F.M. (1993). Anchored narratives: the psychology of criminal evidence. Hemel Hempstead: Harvester Wheatsheaf Westenberg, M.R.M. \& Koele, P. (1993). Klinische besliskunde. In P. Koele \& J. van der Pligt (Red.), Beslissen en beoordelen (pp. 346-374). Amsterdam: Boom.

Witteman, C.L.M. (1992). Competence and performance in belief revision. Dissertation, Utrecht University.
Witteman, C.L.M. \& Kunst, H. (1997). Planning the treatment of a depressed patient. Clinical psychology and psychotherapy, 4(3), 157-171.

Witteman, C.L.M. \& Koele, P. (1999). Explaining treatment decisions. Psychotherapy research, 9(1), 100-114.

Witteman, C.L.M. \& Kunst, H. (1999). SelectCare - in aid of psychotherapists' treatment decisions. Computers in Human Behavior, 15, 143-159

Witteman, C.L.M. (2003). Psychotherapy treatment decisions supported by SelectCare. In F.J. Maarse, A.E. Akkerman, A.N. Brand \& L.J.M. Mulder (Eds.), Clinical assessment, computerized methods, and instrumentation (pp. 144-154). Lisse: Swetz \& Zeitlinger.

Witteman, C.L.M. \& Renooij, S. (2003) Evaluation of a verbal-numerical probability International Journal of Approximate Reasoning, 33(2) 117-131.

Witteman, C.L.M. \& Krol, N.P.C.M. (in press). Knowledge Based Systems: Acquiring, modeling and representing human expertise for information systems. In $\mathrm{H}$. van Oostendorp, L. Breure \& A. Dillon (Eds.), Creation, use and deployment of digital information (chapter 10). Mahwah, NJ: Lawrence Erlbaum Associates.

Woods, D.D. (1993). Process-tracing methods for the study of cognition outside the experimental psychology laboratory. In G.A. Klein, J. Orasanu, R. Calderwood \& C.E. Zsambok (Eds.), Decision making in action: models and methods (pp. 228-251). Norwoord, NJ: Ablex.

Zsambok, C.E. \& Klein, G. (Eds.)(1997), Naturalistic decision making. Mahwah, NJ: Lawrence Erlbaum Associates. 
